\title{
Popular cultures and new performance contexts in contemporary Brazil: the case of Folklore Festival of Olímpia
}

\author{
[Culturas populares e novos contextos de performance no Brasil \\ contemporâneo: o caso do Festival de Folclore de Olímpia
}

\section{Estêvão Amaro dos Reis ${ }^{\mathrm{I}}$}

\begin{abstract}
Pesquisa desenvolvida com o suporte da Coordenação de Aperfeiçoamento de Pessoal de Nível Superior (Capes). Texto traduzido do português por Suellen Gentil and Alicia Magalhães.
\end{abstract}

\begin{abstract}
RESUMO - Este trabalho propõe uma reflexão acerca do papel dos festivais de folclore no mundo contemporâneo. A partir de uma pesquisa etnográfica realizada no contexto do Festival do Folclore de Olímpia - FEFOL - (São Paulo) e junto ao Pastoril Dona Joaquina, de São Gonçalo do Amarante (Rio Grande do Norte), os festivais de folclore serão compreendidos como novos contextos de performance para as práticas dos grupos performativos das culturas populares brasileiras. A reflexão empreendida terá como suporte teórico os conceitos discutidos por Wenger (2OI2) e Turino (2008). • PALAVRAS-CHAVE - Etnomusicologia; comunidades de prática; festivais de folclore;
\end{abstract}

novos contextos de performance. - ABSTRACT - This paper reflects on the role of folklore festivals in the contemporary world. Based on ethnographic research carried out in the context of the Folklore Festival of Olímpia - FEFOL - (São Paulo/Brazil) and with Pastoril Dona Joaquina de São Gonçalo do Amarante (Rio Grande do Norte/Brazil), folklore festivals will be understood as new contexts of performance for the practices of the performative groups of Brazilian popular cultures. The reflection is based on Wenger (20I2) and Turino (2008). · KEYWORDS . Ethnomusicology; communities of practice; folklore festivals; new performance contexts.

Recebido em 3 I de dezembro de 2018

Aprovado em 29 de julho de 2019

REIS, Estêvão Amaro dos. Popular cultures and new performance contexts in contemporary Brazil: the case of Folklore Festival of Olímpia. Revista do Instituto de Estudos Brasileiros, Brasil, n. 73, p. I00-I22, ago. 20I9.

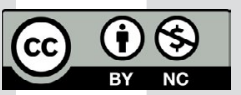

DOI: http://dx.doi.org/Io.II6o6/issn.23I6-90IX.voi73pIoo-I22

I Universidade Estadual de Campinas (Unicamp, Campinas, SP, Brasil). 
The lack of traditional contexts for performances of forms of Brazilian popular culture is a phenomenon that can be observed in the contemporary scenario. This traditional context of performance is here to be understood as the locus in which a particular expression of popular culture originally was developed and manifested, combining necessary material and symbolic conditions so that the performance of the representative group from that locus can follow the characteristics established by its historical tradition. The foundation can come in the form of a mythical narrative, as in the case of the groups belonging to the traditional Brazilian festival called Reinado do Rosário, in the form of a narrative that refers to the ancestors or that is linked to some action of causality, as is the case of the Brazilian festival Folia de Reis.

Folia de Reis, for instance, consists of a journey from the headquarters of Folia to the place where the Festa de Chegada is held. Its traditional context of performance, therefore, consists of the streets and houses of the community which are visited during the journey, and also of the people involved with the performance and tradition. In traditional contexts of performance, different spaces can be integrated and/or merged, as they interact with the performance of the representative group from that locus.

Nevertheless, in the contemporary world, the traditional contexts of performance are increasingly rare, even disappearing in some cases. On the other hand, there is an increasing number of new contexts of performance, generally organized in the form of folklore festivals. The denomination of these festivals range from folklore festivals, international folklore festivals, gatherings of popular cultures, party of the nations, among others. The events take place from the North to the South of Brazil, throughout the year. Similar in form and content, they differ in length and the number of folk groups gathered. The Folklore Festival of Olímpia is one of these events. It is important to note that, although the denominations of these events may bring out the word folklore - implicitly or explicitly - , they are events aimed at bringing together groups of music and dances considered "traditional" or folkloric. In these events, activities are organized around musical performances and in many of them, the presence of musicians in the participating groups is mandatory, barring the participation of groups that do not perform live music.

The factors that have led to the shortage of traditional contexts of performance 
are many, and vary according to the local and characteristic of the manifestation at hand. It ranges from migratory processes from the countryside to the city, to the restriction of the spaces destined to the popular festivals imposed by the Church which forced several groups to seek new spaces for their performances - and even the incorporation of new technologies, such as radio, television and, today, the internet. In some cases, arising from the simple fact of the arrival of electric energy. In the past, in an "ideal" setting, Folia de Reis would travel long distances in the countryside with the revelers staying overnight and being fed as guests in the houses visited during the journey. Antonio dos Reis (resident of Olímpia), for instance, says the journey of his Folia would begin on December I3 (Saint Lucy's Day) and return only on January 6. In the current scenario, on the other hand, many houses in the city do not open their doors to receive performances of Folia de Reis. The same happens with other groups, if in the "old times" Boi de Reis de Cuité (Rio Grande do Norte) partied until dawn, today, their performances can only be seen for a short time at some folklore festivals or some other places where they are invited to perform. In this new scenario, performative groups of popular cultures seek to adapt to a "new world", for which they were not originally envisioned.

The new performative spaces have the characteristic of assembling different expressions in the same space, contrary to what is observed in traditional contexts, which basically have similar expressions: Folias de Reis at Chegadas de Reis; Grupos de Congado at Congado Festivals; Boi groups at Bumba meu Boi and Boi Bumbá Festivals, and so on. In the new contexts of performance there is an equalization of the traditions and the places inherent to each group. In the new space, the revelry no longer sings to pay a promise or to bless and thank the owner of the house for the donation received; the Congos and Mozambicans praise Our Lady of the Rosary in a place different from the place of their party of congado; the numerous groups of Bois (bumba meu boi, boi bumbá) sound their instruments in occasions other than St. John's day (June 24); the pastoris no longer have the courtyards of the churches to greet the infant Jesus.

In these contexts, performances originating from traditions that have often taken centuries to establish themselves become a spectacle (CARVALHO, 2004; REILY, 2000), and are classified as "folklore". Rather than being accompanied by members of their communities, they are now seen by unknown people, often representatives of an elite group who historically hold power. They cease to be participatory performances to become, many times, presentational performances (TURINO, 2008). However, considering this perspective, the reflection undertaken in this paper proposes that, by offering a new space for the practices of these groups, the new performance contexts supply, in some level, the lack of opportunities for traditional performances.

The ethnographic context for the discussion of the issues present in this study includes the Touristic Municipality of Olimpia (São Paulo) and the Folklore Festival of Olimpia - FEFOL, an event on its $53^{\text {rd }}$ edition in 20I7. Being a native of Olímpia, FEFOL has been present in my life since childhood, when I attended the folk groups' performances with my parents. In a second moment, I was also a member of several groups that appeared in the Festival as a musician.

Paul Rabinow (I992) points out that a shared symbols system is established 
between the researcher and the subjects of his research, and only through this system it will be possible to understand the fieldwork entirely. In this case, being "native" made me play the roles of subject and ethnographer simultaneously during the research.

The fieldwork was carried out in FEFOL and with Pastoril Dona Joaquina from São Gonçalo do Amarante (Rio Grande do Norte), and had as main interlocutors the people linked to the organization of FEFOL, members of the participating folk groups and members of Pastoril to Dona Joaquina.

\section{Theoretical Framework}

\section{The studies of folklore and the pejorative vision of the term in Brazil}

From the time of Herder (I744-I803) and Thoms (I803-I885) the studies of folklore were guided in great part by two main characteristics: the "myth of disappearance" and the search for the "national soul". The transformation of popular culture expressions into "folkloric objects", resulting from the literary and philological starting point of these studies (BEN-AMOS, I97I), meant that the collections carried out were first aimed at "preserving" and avoiding their disappearance. Similarly, the "national soul" residing in folklore could only be "rescued" by access to the "pure", simple and naive expressions of the people (REILY, 2000). In a period of consolidation of the Nation States, the urgency contained in both premises led many intellectuals to engage in a real race in search of folklore (ORTIZ, I994), in search of the "pure", not "contaminated", expressions of popular cultures. In Brazil, it was no different.

Fonseca (2009) points out that the transformations experienced in the country during the first half of the twentieth century, among them, the need of establishment, as a nation, in the international scenario, moved a part of the Brazilian intellectuals in search of models of representation that could delimit the construction of a sense of belonging to the nation. Events of a folk nature, including folklore festivals and their congeners are inspired by research carried out in this period. Supported by actions promoted by institutional bodies such as the Campaign for the Defense of Brazilian Folklore, folklore festivals are guided by the "myth of disappearance" and the nationalistic characteristic of the actions undertaken at that time.

The search for the "national soul" - in other words, the search for the identity of the nation - has been the reason behind pioneering research to focus on the "folk object", to the detriment of all sociocultural diversity that shapes and determines it (REILY, I990), thus disregarding the social actors involved. This type of approach made the term folklore acquire a pejorative connotation, extending later to folklore festivals. In this perspective, folklore festivals have come to be seen as spaces of decharacterization and distortion of the expressions of popular cultures, considered as places merely destined to the spectacle, to the usurpation of the traditional knowledge that, uncharacterized, would be presented as pure entertainment.

Carvalho (2004; 1999) uses the terms "spectacularization" and "cannibalization" 
of popular culture to discuss this process. The author argues that inserted in these new contexts and subjected to a "negotiation" mediated by the unequal relationship of power, there would be no other way out for popular cultures, than complete submission to the will of hegemonic power. However, with regard to observable relations of power, generally considered unequal, I believe it is important to bring to the reflection the thoughts of Popoff (2009) proposes the relativization of the concept of subalternity and suggests that, instead of using the concept of subalternity as one that "understands the impossibility of some groups to have their own voice, to manifest their own cultural universe and legitimize it in a diversity context" (Popoff, 2009, p. 9), or, as Carvalho (1999) points out that "the condition of subalternity is the condition of silence", it is possible to think of subalternity as a form of power, which as such, is in constant negotiation with the hegemonic power. This thought corroborates the thinking of Néstor García Canclini (20I0), for whom "negotiation" has always been a very important strategy used by the subaltern sectors.

Regardless of the approach, folklore festivals, as new performance contexts, represent a type of event that is significantly alternating the function and the form of performance of the performative groups of popular cultures, both in Brazil and abroad. Moved by the gradual disappearance of traditional performance contexts, folkloric groups seek to adapt to the new spaces that are created. A similar process can be observed in Encontros de Bandas, events that contributed to the maintenance and restructuring of music bands (REILY; BRUCHER, 20I3).

\section{FOLK GROUPS, COMMUNITIES OF PRACTICE AND PARTICIPATION}

Etienne Wenger (I998) coined the term "communities of practice" to refer to a group of people "who engage in a process of collective learning in a shared domain of human knowledge" (WENGER, 20I2, p. I). Communities of practice involve groups of individuals who meet periodically, having as their goal and common interest the learning and the ways of applying what has been learned (TAKIMOTO, 20I2). Thus, communities of practice can be observed in the most varied formations: "a group of students that defines their identity in the school; a network of surgeons exploring new techniques; a meeting of first-aid managers helping each other deal with problems" (WENGER, 20I2, p. I). They are groups of people driven by a passion for something they do, and they share the ideal that they learn how to do it better by regular interaction (WENGER, 20I2). Although the work of the author does not deal with groups that have a specific goal of musical creation, his work "provides a framework for thinking about local musical communities, whether subaltern or not" (GIESBRECHT, 20I4).

Wenger (20I2, p. I) points out that "learning may be the reason the community comes together or simply the incidental result of the interactions of the members of a group", so a group of people with a common interest, per se, does not characterize a community of practice, since the simple definition of a community of practice does not carry intentionality in itself. In other words, not every community is a community of practice. Having considered this, the author presents three 
fundamental characteristics for the establishment of a community of practice: I) the domain; 2) the community; 3) and practice.

First, the domain constitutes the fundamental element of the group, the identity of a community of practice is defined by a common domain of interest. In the case of folk groups, a performative instance of the popular Brazilian cultures, the musical practice determines the common domain of the community.

The second determining characteristic of the community of practice is the community, formed by individuals and their interactions, which results in the building of relationships. Community members engage in joint activities and discussions while pursuing their interests within the domain. By sharing information, members of the community help each other by building relationships that enable one individual to learn from another.

Practice, properly speaking, constitutes the third element and can be understood as the knowledge shared by members. Members of a community of practice are practitioners and develop a repertoire of resources through shared practice. The community of practice is constituted from the combination of these three elements and the development of these elements in parallel allows the community of practice to be cultivated (WENGER, 20I2).

The concept of communities of practice implies the idea of negotiation, necessary for the good functioning of the community. In the universe of popular cultures, one can observe that any folkloric group undergoes constant negotiation processes in order to be able to function properly - as does any other amateur musical groups of practicians. These groups have specific goals and are "organized around the creation of a certain musical practice" (GIESBRECHT, 20I4), either to hold a feast in praise of their patron saint or to perform at a folklore festival. Its dynamics of operation impose the need of the development of negotiation mechanisms that prevent the occurrence of events that are detrimental to the operation of the group itself, because that depends on the proper functioning and maintenance of the community itself. According to Reily (20I2), one of the ways to avoid the dissolution of groups is to keep everyone singing all the time, so conflicts get smaller and less frequent, because people are immediately involved with the music, as well as being all performing their roles. People already know what they have to do and then they have fun.

As far as communities of practice are concerned, Wenger (20I2) points out that they can interconnect with each other forming a set of communities of practices called "constellation" by the author.

Understood as autonomous communities of practice, folk groups need people to carry out the various activities necessary for the group to function satisfactorily. The functions are distributed in administrative and performative roles. The analysis of the performative roles played by the various groups participating in FEFOL leads us immediately to the concepts of participatory performance and presentational performance, coined by Thomas Turino (2008), when discussing the fields of musical practice, from the idea of the social field of Pierre Bourdieu.

Turino (2008) defines participatory performance as a special kind of artistic practice, whose main characteristic is the absence of distinction between the artist and the audience. In participatory performance, participants and potential 
participants are distributed in functions with different levels of expertise, which means that everyone, without exception, can integrate the performance. The focus of attention is on the activity itself, on the act of singing, of dancing and on the other participants involved with the performance, and not simply on the product resulting from this activity (TURINO, 2008). Beside the absence of distinction between artist and audience, Turino (2008) highlights other characteristics observable in the participatory performance and enumerates a series of sound resources which serve to inspire and increase participation such as: the open form, which makes possible its repetition several times; the subtle delineation that marks the beginning and the end of the performance; the emphasis on the repetition of musical material; the few variations, short texts in the lyrics of the songs, so that the participants can learn quickly; the little space for virtuosity; the dense textures and tones, which allow any "errors" to be covered up².

In contrast to participatory performance, Turino (2008) presents the concept of presentational performance, a type of performance that presupposes the advance preparation by a group of specialized people, seen as artists and not as ordinary people, whose work will be the design and preparation of an artistic spectacle that will be offered to an audience which, in advance, knows that their only function will be that of an spectator.

\section{ETHNOGRAPHIC REPORTS}

\section{The Folklore Festival of Olímpia}

Olímpia is located in the Northwest of the state of São Paulo (Brazil), $450 \mathrm{~km}$ from the capital, also called São Paulo. It is located on the Guarani Aquifer, the largest reservoir of groundwater in the world ${ }^{3}$ and has a population of approximately fifty-three thousand inhabitants, according to data from the 20Io Brazilian Census. In 20I4, Olímpia became a Tourist Municipality and, currently, it receives annually about two million tourists in search of the thermal waters of the city's water parks. In addition, Olímpia is known for its Folklore Festival, held fifty-three years uninterruptedly.

The origins of the Folklore Festival of Olimpia date back to the I950s, in a school environment, with the classes of Professor Victório Sgorlon (I933-20II), at Ginásio Olímpia, aimed at raising students' interest in folklore themes. To this purpose, Sgorlon promoted lectures and organized seminars that culminated in the realization of an exhibition of pieces and crafts in the classrooms of the school.

2 It does not mean that all the listed sound resources will be founded in all the participatory performance (TURINO, 2008).

3 The Guarani Aquifer is present in four South American countries: Argentina, Brazil, Paraguay and Uruguay, and occupies an area of I,200,000 square kilometres. Approximately $70 \%$ of this water reservoir is located in Brazil, spread over the subsoil of Mato Grosso, Mato Grosso do Sul, Goiás, Minas Gerais, São Paulo, Paraná, Rio Grande do Sul and Santa Catarina (FRANCISCO, s. d.) 
In order to obtain support for the research that began from this movement, Sgorlon contacts Rossini Tavares de Lima and Laura Della Mônica who, at that moment, started attending Olímpia, lecturing and directing seminars on the subject. In Sgorlon's words: [...] "we contacted him and he guided us, and Mrs. Laura came to Olimpia at our invitation and taught folklore classes at the school where we worked at that time" (SGORLON, 2OII).

In an interview published in the I97I Folklore Yearbook - a publication edited by FEFOL as of the 7th edition - José Sant'anna (student and continuator of Sgorlon's work) refers to the beginnings of FEFOL, mentioning the initial lectures and the first collections of material that were carried out in 1957, with the aim of "creating in our city [Olímpia] an organ that could protect and disseminate folklore" (SANT'ANNA, I97I). In I965, the exhibits hit the streets of the city and the streets reached the Matriz of St. John the Baptist Square, with the name of Ist Folkloric Festival of Olímpia.

The FEFOL quickly reached an unexpected extent, generating a great repercussion throughout the region. From then on, teachers, university students, folklorists, famous singers, writers and journalists went to Olimpia in August to watch the meeting of folk groups from all over the country. In I966, the Department of Folklore of Olímpia was created and, in the same year, the Folklore Museum of Ibirapuera created a special section for the city of Olímpia. On July 27, I967, Governor Abreu Sodré signed the decree establishing August as the month of folklore. In September I967, Rossini Tavares de Lima, José Sant'anna and Laura Della Mônica, among others, were appointed to form the State Commission for Folklore and Crafts and on May 8, I970, the decree included the inclusion of "Folklore Festival" of Olímpia in the State Tourist Calendar (ANUÁRIO DO FOLCLORE, I975). Today, FEFOL receives almost a hundred folkloric and parafolk groups annually from all Brazilian regions, making it the largest event of its kind in the country.

In the circuit of Brazilian folklore festivals, the term parafolk is used to designate performative groups whose performances are predominantly aimed at the spectacle. The parafolk groups not necessarily are related to the manifestation they will represent and consider the folk groups as a source of research and inspiration for the creation of their artistic works. In these contexts, the term parafolk is in opposition to the term folklore, which refers to "tradition" and "authenticity". Travassos (2002, p. 96) recalls that the Brazilian folklorists gathered in the ambit of the Brazilian Folklore Defense Campaign called the urban groups that exercised the artistic representation of folklore as parafolk.

In fact, no other existing festival of folklore in Brazil provides the gathering of similar quantity and diversity of groups in the same place, congadas, moçambiques, bois, cavalos-marinhos, maracatus, taieiras, parafusos, folias de reis, fandangos, reisados and pastoris are examples of some manifestations observed annually in FEFOL. In addition, FEFOL brings together a large part of what characterizes popular Brazilian cultures, such as songs, dances, traditional children's games, study seminars and typical foods, and also has an appropriate place for its realization, built in the I980s, especially for this purpose. The Recinto de Exposições and Praça de Atividades Folclóricas Professor José Sant'anna, known by the population of Olímpia as "Recinto do Folclore", has an area of $96,800 \mathrm{~m}^{2}$, with parking, sheds of metallic 
structure in the form of tents of varied sizes, free area to set up a large amusement park and an arena theater with the capacity to receive approximately three thousand sitting visitors, as well as two stages, with structures that resemble those used to receive large media shows from the entertainment industry, intended for the performances of participating folk groups, among them Pastoril Dona Joaquina, from São Gonçalo do Amarante (Rio Grande do Norte).

When considering the set of practices that compose the Folklore Festival of Olímpia, it is possible to observe that FEFOL is an invented tradition, following the concept formulated by Eric Hobsbawm \& Terence Ranger (20I4). The practices observed in the new context of performance represented by FEFOL indicate the existence of rules that regulate its operation and at the same time raise values and norms of behavior. Through constant repetition, a relationship of continuity with a historical past is established (HOBSBAWM; RANGER, 20I4)4.

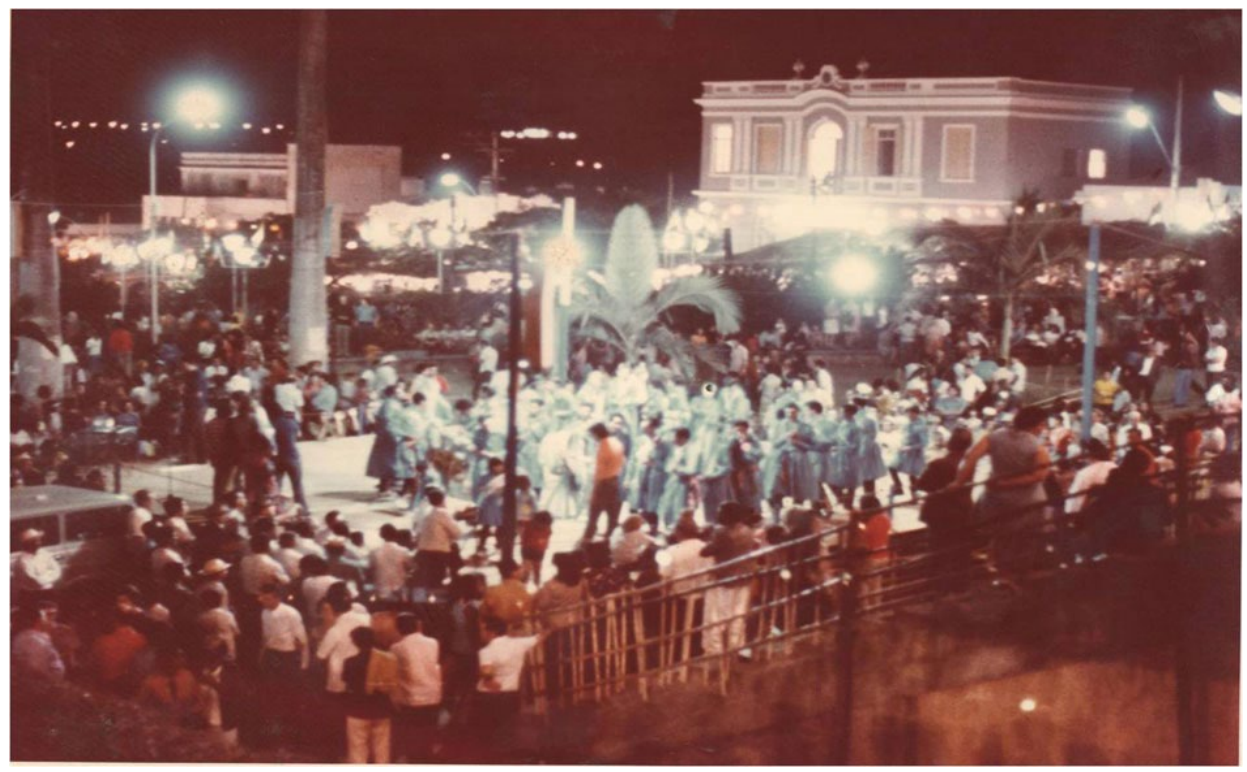

Image I - Folklore Festival in Matriz Square. Source: Archives from FEFOL [I97-?]

4 To know more, see Reis, 2012. 


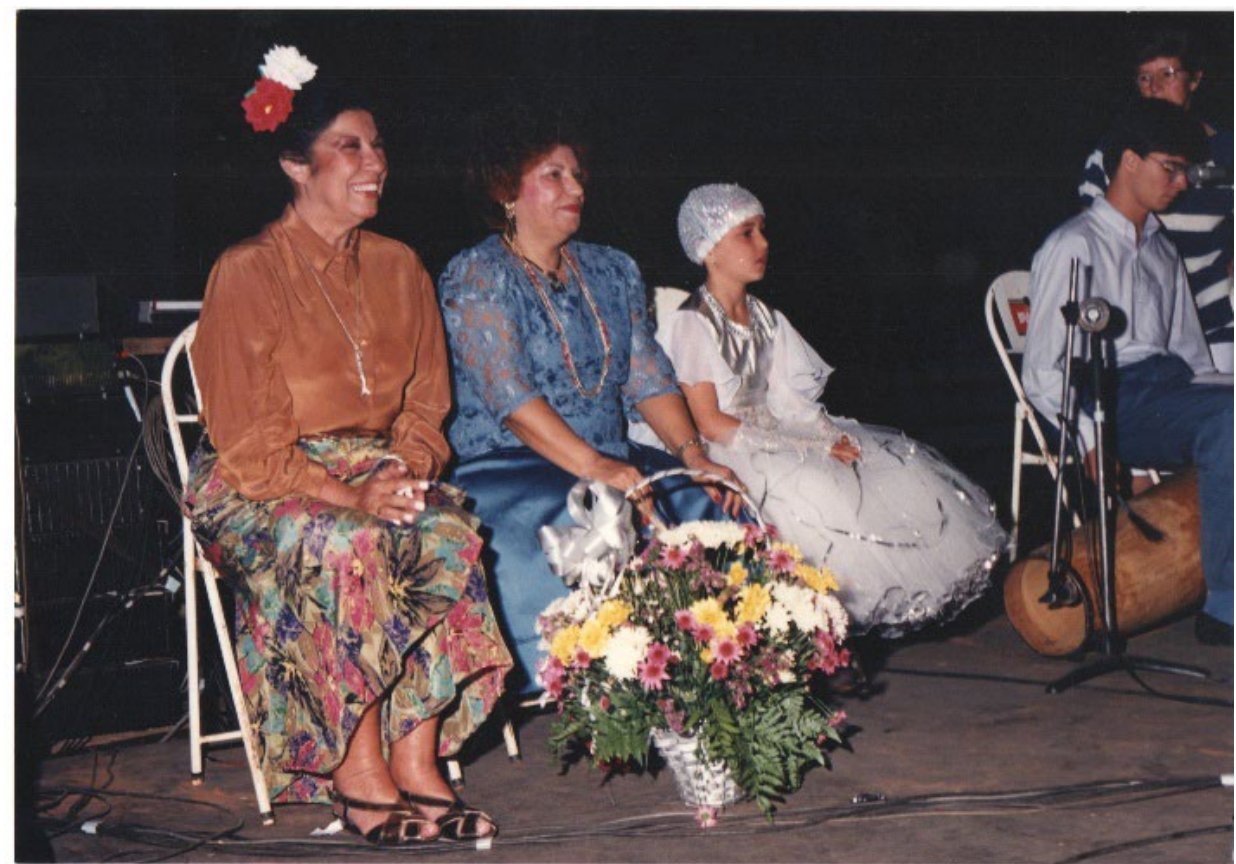

Image 2 - The singer Inezita Barroso in FEFOL. Source: Archives from FEFOL [I98?]

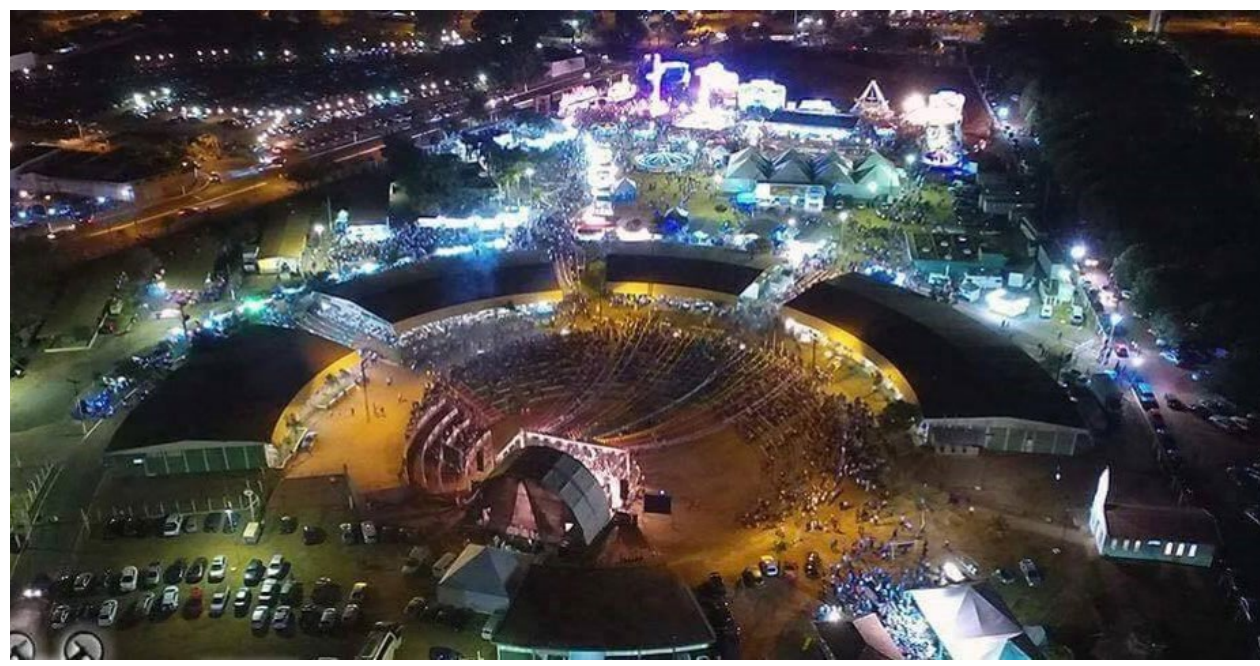

Image 3-Folklore Festival in Recinto do Folclore. Source: Archives from FEFOL [20I-?] 


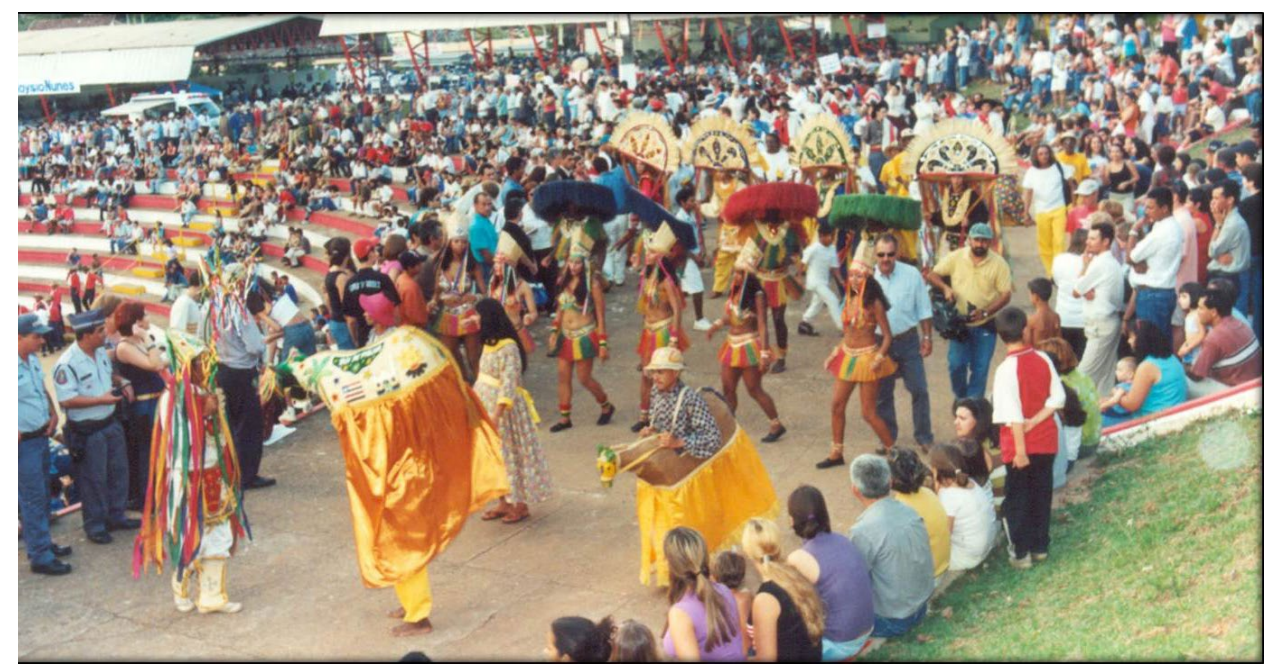

Image 4-Boi de palha - groups in parade in the Recinto do

Folclore. Source - Archives from FEFOL [200-

\section{Pastoril Dona Joaquina}

The pastoril play can be traditionally found in the Northeast of Brazil, mostly in the states of Alagoas and Rio Grande do Norte. It originally represented the visit of pastors to the stable in Bethlehem. At church patios and in front of the nativity play they sang chants and loas 5 waiting for the Christmas Mass.

Founded in 2006 by the teacher Sephora Bezerra, the folkloric group Pastoril Dona Joaquina, from São Gonçalo do Amarante (Rio Grande do Norte), was created in order to renew the pastoril tradition in the state. Alexander Ivanovich, member of Pastoril Dona Joaquina since its foundation, reports the pastoril tradition had been fading for about twenty years.

Teacher Sephora, my cousin, invited me since the beginning, when she had the idea of reestablishing the pastoril. The pastoril tradition had been abandoned in the city of São Gonçalo do Amarante. I believe the last pastoril group that went there was Estrela do Norte [...]. There was no renewal because television made things difficult. (IVANOVICH, 2OI2).

As Ivanovich says, television comes up as a symbol, as a vehicle representing modern times, responsible for the deterioration of traditional practices of pastoril in São Gonçalo do Amarante. A similar case is described by the members of Boi de Cuité (Rio Grande do Norte). The group suffered the same impact as the pastoril groups with the arrival of electric energy to the city of Pedro Velho, and the new means of

5 Loas - declaimed part, usually improvised, in the breaks between pastoril songs. 
entertainment provided by the television. As a result, Boi de Cuité ceased to exist for almost two decades.

According to Ivanovich, in Rio Grande do Norte it is possible to identify two kinds of pastoril: the religious one, also called Lapinha, and the profane one:

[...] the religious pastoril, or Lapinha, tells the story of the pastors that visit the newborn son of God, so they set off looking for the crib, right?! [...] These were performed mostly in church patios, where the religious parties or the nativity play parties, celebrating the birth of Jesus Christ, would take place. (IVANOVICH, 2OI2).

Ivanovich still points out the fact that nowadays pastorils are presented in different periods other than Christmas is due to the "profanization" process the religious pastorils went through: "it has been profanized" [...], so there was no longer a right time for it to be danced, any time would do, they could dance in any festivity [...]” (IVANOVICH 2OI2).

Just like any other manifestation of popular Brazilian culture, which we prefer to call folklore, pastoril presented variations according to the place where it is performed. Luís da Câmara Cascudo (I898-I986), ([I954], 200I, p. 49I) describes a pastoril he saw in a particular way: "The groups sing dressed as pastors, with the characters of an old man, a villain, a country man, a soldier and a sailor". The description of the characters in the pastoril seen by Câmara Cascudo differs from the characters in Dona Joaquina, except for the old man. In Dona Joaquina, the character of the old man is replaced by the character of a clown. Ivanovich describes this transition in São Gonçalo do Amarante as follows:

[...] the religious pastoril, at the time, had the character of the pastor that led the pastors to the crib in Bethlehem. [...] had the character of the organizer [...], a man that took care of the pastors and organized (he had his own pastoril, for example, the pastoril of Mr. so and so), so he was the organizer. And since he was someone who joked about everything, even to bring some happiness to the audience, he became a funny character. After that, it didn't take much to become a clown. (IVANOVICH, 2OI2).

The character of organizer explained by Ivanovich is very common in the universe of folkloric groups. The organizer, usually called "owner" of the game ${ }^{6}$, is the person in charge of the maintenance of the group, providing the needed conditions for it to work. Ivanovich is an heir to a traditional circus family from Rio Grande do Norte that, nowadays outside the circus, performs in birthday parties and small shows to which he is hired, but also on the streets of São Gonçalo do Amarante.

In Pastoril Dona Joaquina, Ivanovich is the clown Xapuleta: "I come from the circus, the popular clown. Actually, Xapuleta, the pastoril's clown, is like that. But the clown I usually play, the circus clown, the clown from the streets, is Tamborete de Forró. There are two clowns [...] (IVANOVICH, 2OI2). He also emphasizes that in the

6 All in all, game is a term used by the Brazilian folklore groups, especially in the Northeast: game of boi, game of cavalo marinho, game of caboclinhos, game of pastoril. 
game of pastoril the clown is the character responsible for leading the performance, which makes his pastoril a profane one.

[...] The profane pastoril was a way that the girls who spent the whole year in church patios being pastors let loose and sang songs that were not praising the son of God. After its creation, it gathered with clown jokes, and songs started to get spicy [...]. (IVANOVICH, 20I2).

Ivanovich states that the "profanization" process gave rise to the profane pastoril, the kind of pastoril to which Dona Joaquina belongs.

Aside from the characters Diana and clown Xapuleta, the pastoril of São Gonçalo do Amarante has approximately twenty members, considering dancers and musicians. The dancers are exclusively females, divided into two groups of five, the blue strands and the red strands. The character Diana is responsible for mediating the conflicts between the two groups. The number of musicians that accompanies the group may vary from six to eight members.

The strand dancers wear light cloth dresses, just a bit above the knee, decorated with sequins on the waist and cleavage. They wear white flat shoes and carry a crown decorated with the same sequins as the dresses. The garments are worn by both strands differing only in color, each strand with their respective color. The character Diana is the only one among the dancers whose garments are different. Since she is the mediator of the conflict between the blue and the red strands in the performance, she wears a white dress full of references to both strands. Her crown is divided symmetrically with the colors red and blue.

The clown wears a blue shirt, plaid pants with suspenders and a suit with a sunflower on the lapel. A classical clown nose and traditional make up, a red and blue bowler hat, red socks and sneakers. He also has a type of cane with the nickname of macaxera. The clown is responsible for the maintenance and progression of the performance, so he stimulates the pastors in a playful way and interacts with the audience with jokes and games.

Invited for the first time in 2006, Pastoril Dona Joaquina participated in seven consecutive editions of FEFOL, 2007, 2008, 2009, 2010, 2011, 2012 and 20137.

7 In 2014 the group was invited but was unable to attend. 


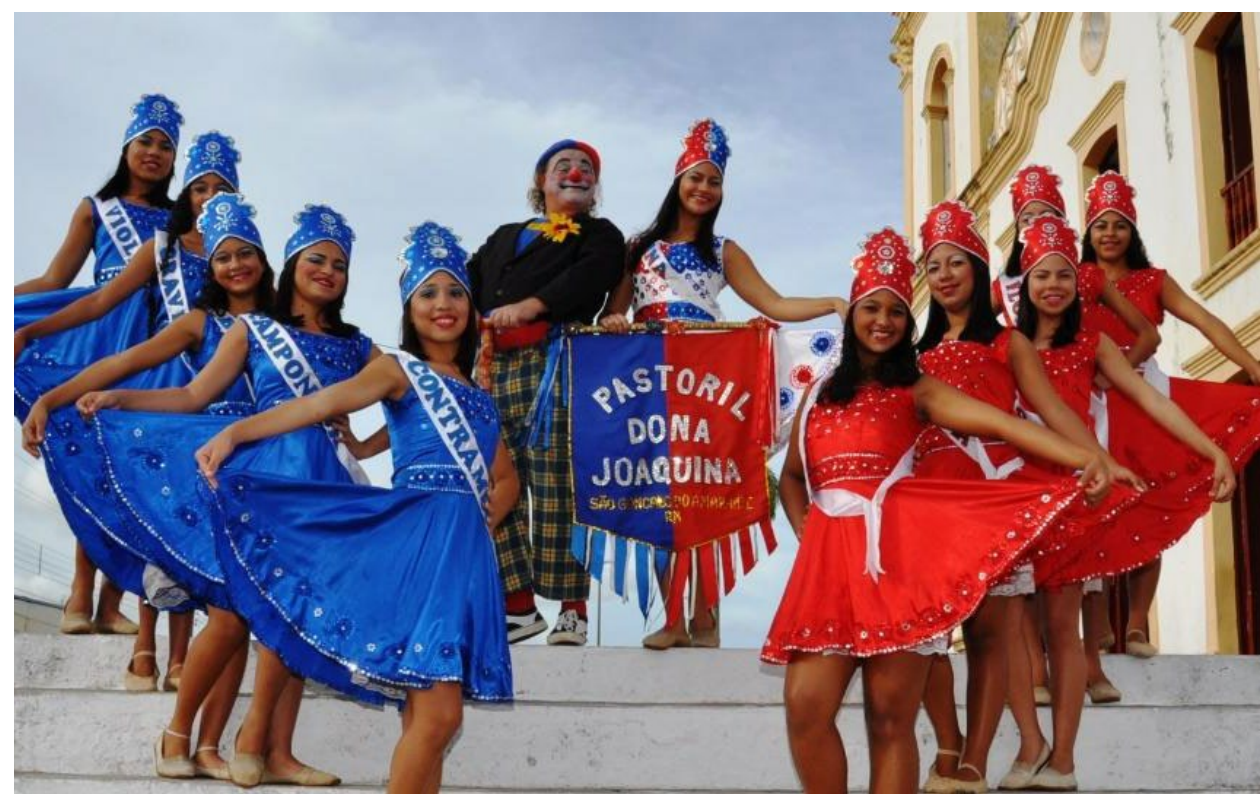

Image 5 - Pastoril Dona Joaquina in São Gonçalo do Amarante. Source: Carlos Isaías [2oI?]

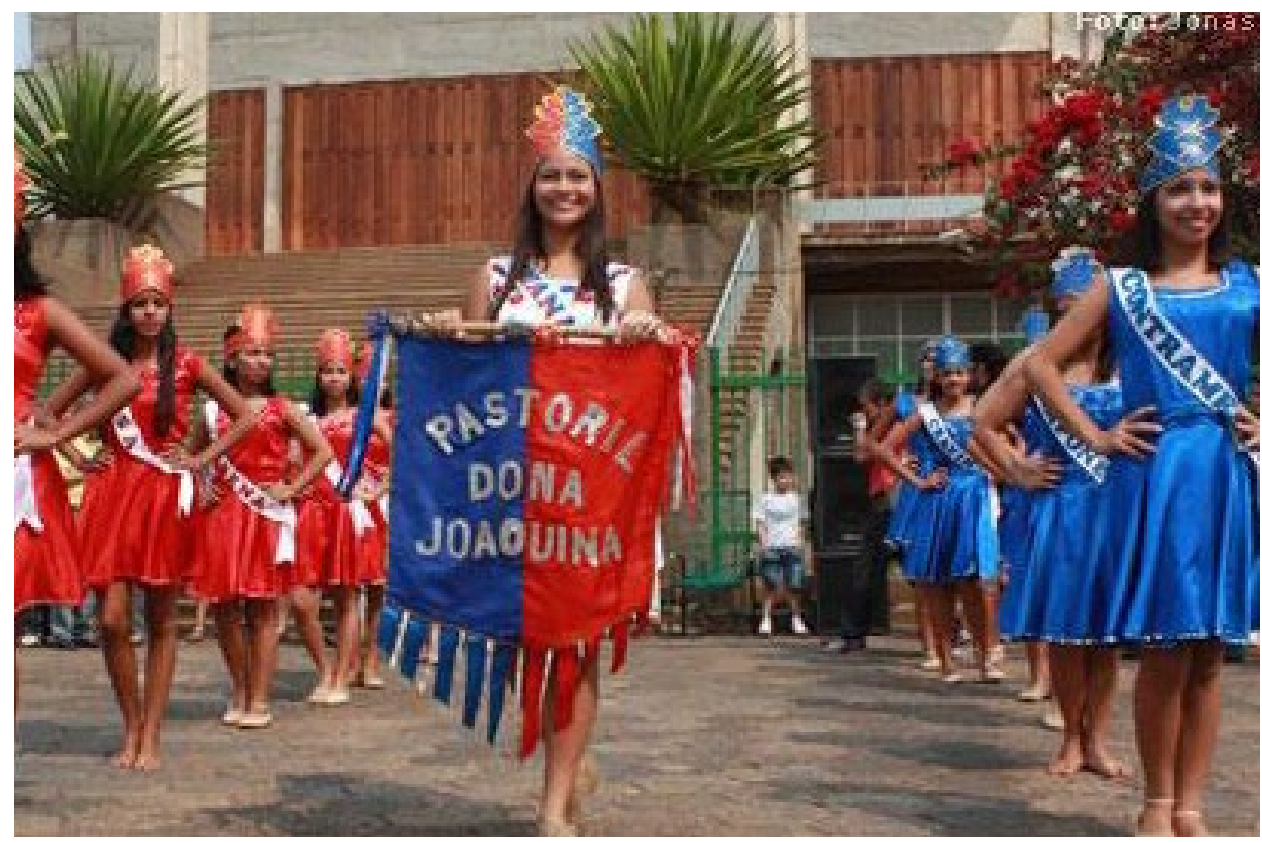

Image 6 - Pastoril Dona Joaquina in Olímpia (Praça da Matriz). Source: Jonas Olmos [20I2] 
Câmara Cascudo ([I954], 200I) describes the formation of the pastoril's orchestra as follows: composed of woodwinds and string instruments, cavaquinho and guitars and a wind instrument as a soloist. In 20I2, on its performance on the 47th Folklore Festival of Olímpia, Pastoril Dona Joaquina had eight musicians and worked only with instruments of professional level. The instrumentation was arranged with a zabumba or bass drum (similar to a martial bass drum, used in fanfares and marching bands); a caixa clara or snare drum; a tambourine (made of leather or nylon); a cavaquinho; a guitar (six strings); a brass section with a tenor saxophone, a trombone and a trumpet; feminine and masculine voices. The clown Xapuleta not only played the role of an organizer in the performance, but also sang. Amateur and professional musicians played together. The repertoire was dynamic and joyful and comprised mostly rhythms of forró (marchs, baiões, arrasta-pés), but also samba. The lyrics talked about themes of game of pastoril and most of them had a twofold ambiguous sense.

According to Francisco de Assis Alves da Silva Júnior and Felipe Eric, musicians in charge of the songs of Pastoril Dona Joaquina, the songs are chosen based on the traditional pastoril repertoire and adapted to the group's needs. They said the accordion is an instrument frequently used in traditional pastoril repertoires in Rio Grande do Norte, except in the region of São Gonçalo do Amarante, in which the accordion is replaced by brass instruments.

Silva Júnior states that Felipe Eric $^{8}$ sometimes "exaggerates" in the construction of the musical arrangements, for having an erudite education in music. "[...] sometimes his scores get too erudite. So, I tell him to ease up a bit, not to make an old song too complicated" (SILVA JÚNIOR, 20I2). Aside from the adaptations made from the traditional pastoril repertoire, new songs are composed for the group. Ivanovich and Felipe are amongst the songwriters. When the arrangements are finished they are put through the appraisal of all the group members before being added to the repertoire?.

Silva Júnior was responsible for Felipe Eric's contact with the universe of Northeastern folklore, a contact Eric has maintained and deepened ever since. In the 48th edition of FEFOL, Felipe stated that he not only had made new friends and played as a guest musician in the performances of many folkloric groups in FEFOL, but also got to know a new instrument, the viola de coxo (Mato Grosso). In 20II, Pastoril Dona Joaquina was on the cover of the folklore Yearbook and on the poster of the 47th edition of the Folklore Festival of Olímpia, the edition that paid tribute to the state of Rio Grande do Norte.

8 In 20I8, Felipe Eric got a degree in Music at the Federal University of Rio Grande do Norte. Felipe plays the flute, the piccolo, the accordion and the cavaquinho.

9 In 20I3, Edward Marques da Silva, musician and songwriter from Olímpia, composed a song that was added to the repertoire of Pastoril Dona Joaquina. 


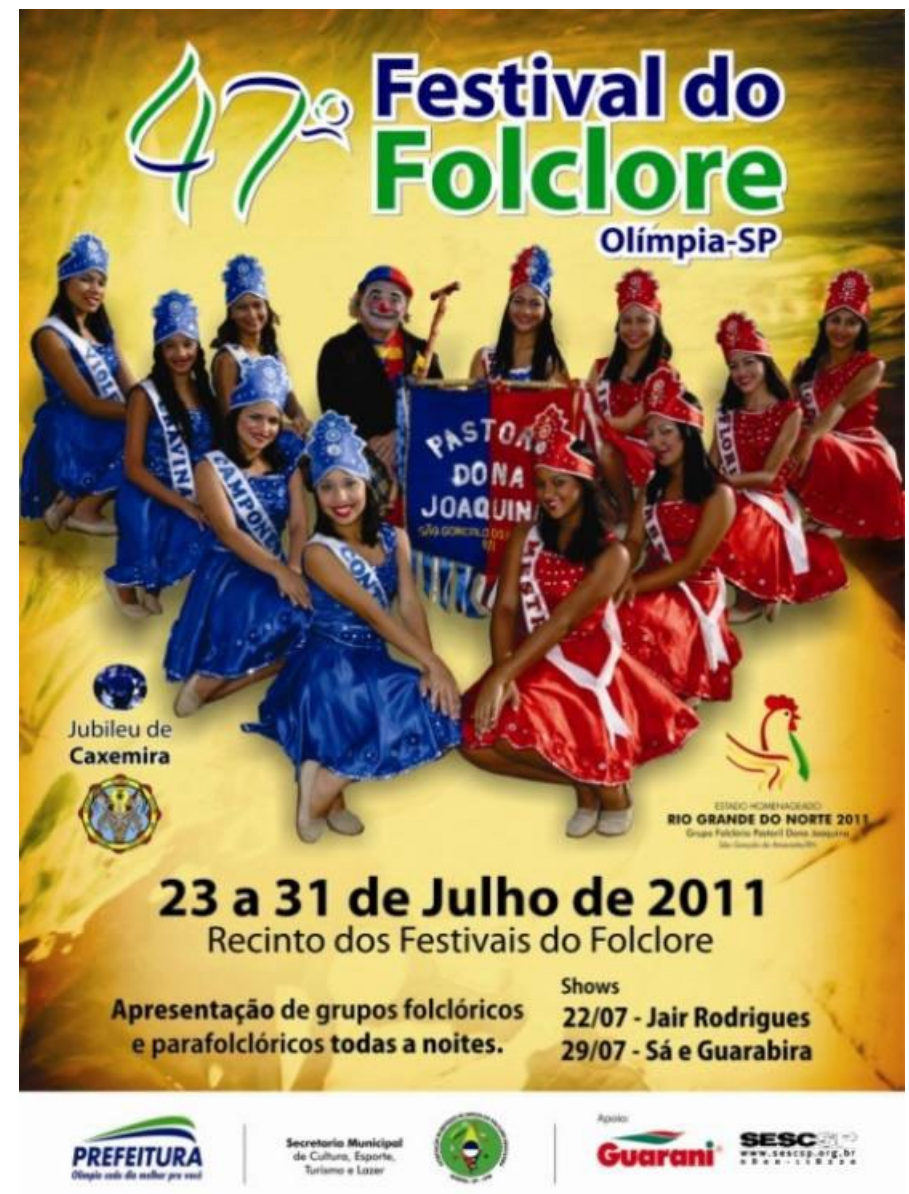

Image 7- Poster of the 47th FEFOL. Source: Jonas Olmos [20I2]

\section{Pastoril Dona Joaquina in São Gonçalo do Amarante}

Ivanovich says that the situation of folklore groups in Rio Grande do Norte is precarious and emphasizes that before being officially invited by the organizing committee of FEFOL, Pastoril Dona Joaquina did not know about the event.

Until then we didn't know about the Festival, that was in 2007. My cousin Sephora said a thing or two about this Olímpia Festival, but until then we had no idea how great it was. [...] [In São Gonçalo] there isn't any public entity that takes care of that [...] we end up left to our own devices [...]. (IVANOVICH, 20I2).

In 20I2, during the project Agosto de Alegria, in Natal, we were able to verify what has been said by Ivanovich. In spite of being intended to celebrate the 
month of folklore and of being organized by public entities, the project was poorly structured.

However, it is important to note that traditionally these groups' performances (Pastorils, Ternos de Congo, etc.) are done in residences or church patios amongst the nativity plays, similarly to the Folia de Reis, which dismisses the need for microphones or sound equipment. The very stage of these performances - the living room of a home, the patio of a church - added to the interaction of the audience (Turino, 2008), makes the setting an ideal environment. However, when taken to the context of a formal performance (Turino, 2008), as in the case of the project Agosto de Alegria, some equipment is needed to aid the sound projection. That is what we meant when we stated that it was poorly structured.

The account of Ivanovich shows the impact the new context of performance of FEFOL made in the group.

We were surprised when we came here, by the way they welcomed us. That made us want to go for it, to participate in more festivals, to show our work. [...] Other groups started restructuring themselves because of the encouragement we received here and passed to them [...]. (IVANOVICH, 2OI2).

FEFOL appears as a counterpoint to the places Pastoril Dona Joaquina usually performed in Rio Grande do Norte, i.e., a place that values the work of the group.

This trip we made to Olímpia is what stimulated us to spread the word and make people want to come here as well. [...] Even children started to make groups. There's a cultural point making a Boi Mirim and a Pastoril Mirim (folkloric groups with children), you know? So, they grow up with the will to participate. [...]. Nowadays, there are ex-members of Pastoril Dona Joaquina in the university [UFRN], becoming professional dancers, participating in the folkloric events of the university. (IVANOVICH, 2OI2).

The feeling of being valued in the new context of performance goes beyond the period of FEFOL, with results that affected even the traditional performance context of the group.

\section{The Performance of Pastoril Dona Joaquina at FEFOL}

On the stage of the 47th FEFOL, the musicians of Pastoril Dona Joaquina were set on stage, the clown Xapuleta entered testing and playing with the wireless microphone. He walked to the center of the stage and announced that the game was about to begin, Pastoril Dona Joaquina calls their performance a journey ${ }^{\text {to }}$.

Io The translation of the description that follows was carried out emphasizing the ideational elements of the speech. In its original form, in Brazilian Portuguese, the speech is permeated with rhythmic elements, such as rhymes, limericks and word plays, that are associated to this genre. 
Hey, hey, oi, oi! It's alive! It's alive.

Good evening once more,

Good evening Olímpia, good evening Brazil!

Good evening to everyone, to our arrival.

Here is a clown who's not silly at all.

I've come to bring the girls of Pastoril Dona Joaquina

To dance a journey.

Xapuleta goes in the direction of the official team's camera that is recording the festival ${ }^{\text {II: }}$

Today we'll see a conflict

That will knock your socks off,

We have the red strand

That you may enjoy."

Faces the audience, points to the blue strand and bows down to Diana:

We also have the blue strand

That makes me speechless,

But, we have Diana

That no one can fight for,

For she is the one

The only owner of my heart!

Faces the musicians and shouts:

Go conductor!

The musicians start playing arrasta-pé with an introduction made by the brass sections and the pastors get on stage in two lines conducted by Diana, who carries the group's flag. The dancers set the pace, the right foot goes to the front and then back, following the arms that make wide wave-like movements. The clown dances in the middle, between the two strands. When the singing part begins, the dancers go to the back, changing the scenario. The rehearsed gestures follow the lyrics and the strands copy each other's movements. They want to hold the attention of the public, for in the end it will decide which one is the winner.

[brass introduction]

Excuse me sir owner of the house,

The pastoril wants to play a game [encore]

I've been looking for a pastor,

I found her just now [encore]

II The recording of FEFOL's main stage is transmitted live to the festival's website. 
And we came to worship

Jesus was born to save us [encore]

It's my opinion and what I think it's right,

To love the reds with a joyful heart

And to love the blue strand with a joyful heart too

But I'm tired from running

So tired I got to sit down [encore]

I've been looking for a pastor,

I found her just now [encore]

But I'm tired from running

So tired I got to sit down [encore]

I've been looking for a pastor,

I found her just now [encore]

[brass finishing introduction]

The journey of Dona Joaquina comprises a set of songs. The first song asks permission for the owner of the house to come in, a common attitude in the performance of folkloric groups that refers to its traditional context, when they visit the houses of the community. After the opening song, a samba with double sense lyrics comes right after the clown's line, "Oh, I like this sambinha, shake it!" And plays with the dancers that have their hands on their waists or are holding the tip of the dress in a movement of sarandeio ${ }^{\mathrm{T2}}$ and move their hips to the rhythm of the song.

[saxophone introduction]

My money doesn't buy a fan,

Shake it, shake it pastor, shake your fan

Oh girl, when I die

Don't bury me in a shallow grave

So a cockroach doesn't come

And bite my leg

Shake it, shake it pastor, shake your fan

Oh girl, my girl

With the body of a twisted line

May God want you to be

The end of my life

Shake it, shake it pastor, shake your fan

Oh, my boat doesn't flow

And my boat doesn't sink

Oh, honey I want to see

Your skirt swaying

Shake it, shake it pastor, shake your fan

[saxophone introduction]

I2 Sarandeio - holding the tip of a skirt making oscillating movements, making waves with the skirt. 
From song to song, the journey continues until the end of the performance, when clown Xapuleta asks the audience which strand is the winner. After choosing which one is the winning strand, the group sings a final song and leaves the stage. Many times the clown declares a tie, making everyone happy.

\section{FinAL REMARKS}

We can understand the Pastoril Dona Joaquina as a community of autonomous practice (WENGER, 20I2), with defined administrative and performative roles, a board of directors, musicians and dancers, which allows the group to do a good job.

The board is responsible for maintaining the group, as the musicians and dancers share the performative roles. The performative roles attributed to the dancers correspond to the characters of Diana, shepherds and the clown. The shepherds are divided into two groups: the blue string and the red string. They are compound exclusively by young women. In a contest to choose the best string amongst the two, the shepherds sing and dance for the attention of the audience. The character of Diana is responsible for the mediation of the dispute, interacting with the shepherds during the game. The clown is responsible for the maintenance and running of the performance.

Although the FEFOL stage structure favors groups whose performances are predominantly presentational, there is place for participatory performance, the main characteristic of the folkloric groups in FEFOL. In the main stage of FEFOL, Pastoril Dona Joaquina presents its journey to an audience that watches the performance attentively, although they participate in some moments driven by the jokes of the clown Xapuleta. The audience is often invited to take the stage to sing and dance with the group. In these moments, the performance gradually begins to present the characteristics observed in the participatory performance, corroborating with Turino (2008), whose work points out the possibility of the existence groups, whose performances simultaneously present characteristics observed both in the field of participatory performance and in the field of presentational performance.

As a community of practice, the interest of Pastoril Dona Joaquina is the tradition of Pastoril from São Gonçalo do Amarante. Through this common interest, which involves the songs and dances attributed to the performances by the group, its members gather together with the purpose of renewing this tradition in the city and strengthen their relationships as a group and with the community itself. The shared knowledge in its practice develops a repertoire of resources that will be used by the whole group. Thus, through the shared practice provided by interaction, Pastoril Dona Joaquina (re)creates its performative repertoire, a repertoire that allows the group to flexibilize their practices according to the context, whether in São Gonçalo do Amarante or in the stages of FEFOL.

In addition, FEFOL can be examined as a "constellation", a term used by Wenger (20I2) to refer to an interconnected set of communities of practice. The "constellation" 
of communities of practice observed in the organizational structure of FEFOL has the Festival itself as a common domain of interest, where members of the community are equivalent to the communities of practice formed by the folk groups, the organizing committee and the other groups involved, whose practice represents shared knowledge among the various interconnected communities. The knowledge that is produced having as reference the FEFOL itself results in its excellent functioning and maintenance during all those years of its accomplishment.

Besides, the beginning of a process of renewal of the pastoril tradition in the region of São Gonçalo do Amarante after the participation of Pastoril Dona Joaquina at FEFOL, as said by Ivanovich, indicates that the insertion of Pastoril Dona Joaquina's practices in a new context of performance enhances the symbolic capital (Bourdieu, 2007) of the group - in the sense that any artistic or cultural production would become a symbolic good. Adding this case to the exchange of experiences of diverse folkloric groups in FEFOL shows their changes when returning to their homes feeling empowered. A feeling that affects the whole group and everyone around it, promoting the "rebirth" of folkloric groups in São Gonçalo do Amarante.

Thus, Pastoril Dona Joaquina follows their path changing and giving (a new) meaning to their traditions and adapting to new performance contexts in the contemporary world.

\section{SOBRE O AUTOR}

ESTÊVÃO AMARO DOS REIS é pesquisador do

Projeto Temático "O musicar local: novas trilhas para

a etnomusicologia" (Fapesp/Unicamp/USP).

E-mail: amarodosreisestevao@gmail.com

https://orcid.org/o000-0002-8792-0242

\section{REFERÊNCIAS}

ANUÁRIO DO FOLCLORE. Departamento de Folclore do Museu de História e Folclore “Maria Olímpia” e Comissão de Folclore (Conselho Municipal de Cultura), da Prefeitura Municipal de Olímpia. Olímpia, ano XVII, n. 20, I996.

. I97I a 20II. Departamento de Folclore do Museu de História e Folclore "Maria Olímpia” da Prefeitura Municipal de Olímpia. Olímpia.

BEN-AMOS, Dan. (I97I). Hacia una definición de folklore en contexto. In: BLACHE, M. Narrativa folklórica (II). Buenos Aires: Fada, I995

BOURDIEU, Pierre. A economia das trocas simbólicas. Introdução, organização e seleção Sergio Miceli. Tradução Sergio Miceli et al. 6. ed. São Paulo: Perspectiva, 2007. (Coleção estudos; 20 / dirigida por J. Guinsburg). 
. O poder simbólico. Coleção coordenada por Francisco Bethencourt e Diogo Ramada Curto. Tradução Fernando Tomaz. Rio de Janeiro: Bertrand Brasil, 1989. (Coleção Memória e Sociedade).

BRANDÃO, Carlos Rodrigues. O que é folclore. 4. ed. São Paulo: Brasiliense, I982.

CARVALHO, José Jorge. O olhar etnográfico e a voz subalterna. Série Antropologia. Brasília: I999, p. I-30.

. Metamorfoses das tradições performáticas afro-brasileiras: de patrimônio cultural a indústria de entretenimento. In: Celebrações e saberes da cultura popular: pesquisa, inventário, crítica, perspectivas. Rio de Janeiro: Centro Nacional de Folclore e Cultura Popular/Iphan, 2004, p. 65-83. (Série Encontros e Estudos, n. 5.)

CASCUDO, Luís Câmara da. Dicionário do folclore brasileiro. II. ed. São Paulo: Global, $200 I$.

FELIPE, Eric. [inédito]. Entrevista concedida a Érica Giesbrecht, em ago. 20I2. Arquivo de áudio em formato mp3.

FONSECA, Edilberto José Macedo. Etnomusicologia e folclore: o caso do levantamento folclórico de Januária-MG e as gravações etnográficas das músicas de tradição oral no Brasil hoje. Música e Cultura, v. 4, 2009, p. I-IO.

. Reis dos temerosos: comunidades, identidades e circuitos musicais em Januária-MG. In. Claves, v. I, p. 2I-38, 2013 .

. A ideia de folk e as etnomusicologias. Debates, v. I2, 2014, p. 79-9I.

FRANCISCO, Wagner de Cerqueira e. Aquífero Guarani. Brasil Escola. Disponível em: <http://www.brasilescola.com/brasil/aquifero-guarani.htm >. Acesso em: I7 nov. 2015.

GARCÍA CANCLINI, Néstor. Culturas híbridas: estrategias para entrar y salir de la modernidad. I. ed. 3. reimp. Buenos Aires: Paidós, 2010.

GIESBRECHT, Érica. "Não há música sem dimensão política”: conversa com Suzel Reily sobre música, etnomusicologia e os estudos acerca da cultura popular brasileira. [entrevista a Érica Giesbrecht e Carla Delgado de Souza]. Proa. n. 4, v. I, 20I4.

HOBSBAWM, Eric; RANGER, Terence. A invenção das tradições. Traduzido por Celina Cardim. 3. ed. Cavalcante. Rio de Janeiro: Paz e Terra, I997.

IVANOVICH, Alexander. [inédito]. Entrevista concedida a Estêvão Amaro dos Reis, em ago. 20I2. Arquivo de áudio em formato mp3.

LUCAS, Glaura. Os sons do Rosário: o Congado Mineiro dos Arturos e Jatobá. Belo Horizonte: UFMG, 2002. . O batuque e os "Filhos de Zambi”: recriações sociomusicais na Comunidade Negra dos Arturos. In: ENCONTRO DA ASSOCIAÇ̃̃O BRASILEIRA DE ETNOMUSICOLOGIA, 3., São Paulo. Anais..., 2007, p. I-7.

ORTIZ, Renato. A moderna tradição brasileira. 5. ed. São Paulo: Brasiliense, I994. . Românticos e folcloristas. São Paulo: Olhos d'água, s. d.

POPOFF, Marcela Liliana Caetano. As perversões ficcionais da representação: de Vaimaca Peru a Antonio Conselheiro. 233 f. Tese (Doutorado em Letras). Faculdade de Letras, Universidade Federal de Minas Gerais, Belo Horizonte, 2009.

RABINOW, Paul. Reflexiones sobre um trabajo de campo em Marruecos. Madrid: Ediciones Jucar, I992.

REILY, Suzel Ana. Musicalidade, colonialismo e comunidades de prática nas Minas Gerais do século XVIII. (não publicado), $20 I 0$.

. Jornadas encantadas: as folias de Reis do sul de Minas. In. Festas populares, folias de reis. Textos do Brasil. Ministério das Relações Exteriores. Brasília, 2006.

. Voices of the magi: enchanted journeys in Southeast Brazil. Chicago: University of Chicago Press, 2002.

. Folk music, art music, popular music: what do these categories mean today?. [S.l]., 2000. 
_. Manifestações populares: do “aproveitamento" à reapropriação. In: REILY, S. A.; DOULA, S. M. (Org.). Do folclore à cultura popular. ENCONTRO DE PESQUISADORES NAS CIÊNCIAS SOCIAIS. São Paulo: Departamento de Antropologia da Faculdade de Filosofia, Letras e Ciências Humanas da USP. Anais..., I990, p. I-3I.

REIS, Antonio dos. [inédito]. Entrevista concedida a Estêvão Amaro dos Reis, em 20II, 20I4, 20I5, 2016. Arquivo de áudio em formato mp3.

REIS, Estêvão Amaro dos. Práticas contemporâneas das culturas populares brasileiras: o Festival do Folclore de Olímpia. 267 f. Tese (Doutorado em Música). Instituto de Artes, Universidade Estadual de Campinas, Campinas, 2016.

. O Festival do Folclore de Olímpia, São Paulo: uma festa imodesta. I65 f. Dissertação (Mestrado em Música). Instituto de Artes, Universidade Estadual de Campinas, Campinas, 2012.

SANT’ANNA, José. Anuário do folclore. Departamento de Folclore do Museu de História e Folclore "Maria Olímpia” da Prefeitura Municipal de Olímpia. Olímpia, I97I.

. O Festival do Folclore de Olímpia, São Paulo: uma festa imodesta. 20I2. I65 f. Dissertação (Mestrado em Música). Instituto de Artes, Universidade Estadual de Campinas, Campinas, 2012.

SGORLON, Victório. [inédito]. Entrevista concedida a Estêvão Amaro dos Reis, em mar. 20II. Arquivo de áudio em formato $\mathrm{mp} 3$.

SILVA JÚNIOR, F. A. [inédito]. Entrevista concedida a Estêvão Amaro dos Reis, em ago. 20I2. Arquivo de áudio em formato mp3.

TAKIMOTO, Tatiana. Afinal, o que é uma comunidade de prática? Blog da SBGC (Sociedade Brasileira de Gestão do Conhecimento), 23/4/20I2. Disponível em: <http://www.sbgc.org.br/blog/afinal-o-que-e-uma-comunidade-de-pratica $>$. Acesso em: I8 fev. 2016.

TRAVASSOS, Elizabeth. Recriações contemporâneas dos folguedos tradicionais: a performance como modo de conhecimento da cultura popular. In. TEIXEIRA, J. G. J. C. (Org.). Patrimônio imaterial, performance cultural e (re) tradicionalização. Brasília: ICS/UnB, 2004.

TURINO, Thomas. Social identities and indigenous musical practices. In: and popular music in Zimbabwe. Chicago: University of Chicago Press, 2000. . Music as social life: the politics of participation. Chicago: University of Chicago Press, 2008.

WENGER, Etienne. Communities of practice: learning, meaning, and identity. Cambridge, University Press, I998.

. Communities of practice and social learning systems: the career of a concept. 20I2. Disponível em: <http://wenger-trayner.com/wp-content/uploads/20I2/oI/o9-Io-27-CoPs-and-systems-v2.oI. pdf $>$. Acesso em: I8 fev. 2016. 